\title{
ПРІОРИТЕТИ ІНКЛЮЗИВНОГО РОЗВИТКУ РЕГІОНІВ УКРАЇНИ
}

\author{
Попадинець Назарій Миколайович \\ кандидат економічних наук \\ ДУ «Інститут регіональних досліджень ім. М.І. Долішнього НАН України» (м.Львів, Україна) \\ ORCID: 0000-0002-7556-6135 \\ popadynets.n@gmail.com
}

У статті досліджено актуальні питання інклюзивного розвитку. Обгрунтовано необхідність інклюзивного розвитку регіонів України та визначено основні передумови переходу на інклюзивний розвиток. Висвітлено закордонний досвід інклюзивного розвитку регіонів. Окреслено основні чинники інклюзивнотсі та шляхи їх застосування.

Ключові слова: інклюзивний розвиток, інвестиції, інновації, конкурентоспроможність, мобільність населення, регіони України.

DOI: https://doi.org/10.32845/bsnau.2019.2.18

Постановка проблеми. У сучасному світі глобальний пріоритет усе більше «опановує масами» в розвинених і країнах, що розвиваються. На думку почесного голови Організації підтримки глобальної цивілізації Чжан Шаохуа, за часів племен інтереси племені були найвищі. За часів держав на чолі були інтереси держави. В епоху міждержавних відносин пріоритетні інтереси міждержавних об'єднань. Згідно з цією логікою в сучасному світі інтереси всього людства мають перевершувати будь-які другі інтереси. Але суперечки між людьми в сфрері інтересів не мають припинитися» [1].

Глобальний пріоритет вже склав основу нової парадигми розвитку світу і національних держав. Тому процеси глобалізації показали соціальну нерівність і поляризація між різними державами, тобто сформувалися два полюси: дуже багаті країни, постійно нарощують власну перевагу, і дуже бідні, які практично втратили перспективу виходу із зачарованого кола бідності. Багато країн, що відносяться до периферій системи міжнародних відносин, «потрапили в пастки глобалізації». Стрімко втрачаючи національну ідентичність, вони не отримують взамін ні адекватного розвитку якісно нових продуктивних сил, ні нарощування національної могутності в інноваційному, технологічному, освітньому, науковому і духовному відношенні. У державах посилилося розшарування націй, що веде до серйозних соціальних наслідків.

Таким чином, незважаючи на значне домінування США, Японії та деяких країн Західної Європи, сьогодні у світі побутує думка, що глобальний пріоритет має відображати інтереси всього людства, а не нечисленної групи розвинених країн. У такому випадку для успішного здійснення цього задуму економіка має стати не тільки стійкою, але і більш інклюзивної і справедливою, адже основне значення в забезпеченні інклюзивного економічного зростання, спрямованого на підвищення добробуту людини, має наявність усіх видів ресурсів.

Так як і в країнах світу, в Україні в реаліях адміністративно-територіальної реформи, інклюзивний розвиток економіки може відіграти надважливе значення, стати основою підвищення добробуту населення.

Аналіз останніх досліджень. Питаннями інклюзивного розвитку, зокрема: узагальненням теоретико-методологічних засад, розкриттям сутності інклюзивного розвитку світового господарства, розглядом європейських підходів до розуміння сутності інклюзивної моделі розвитку економіки в сучасних умовах, займалася низка науковців таких, як:

Л. М. Ємельяненко, А. В. Кожина, О. Д. Прогнімак, Л. І. Федулова, О. В. Хоменко та ін. Однак, варто зазначити, що на сьогодні ще дуже мало праць присвячено інклюзивному розвитку України в регіональному розрізі.

Метою статті $€$ визначення основних проблем інклюзивного розвитку регіонів України.

Виклад основного матеріалу. Концепція інклюзивної розвитку є досить успішною спробою осмислення глобального пріоритету в якості основи плідного та справедливого розвитку держав, зокрема зміцнення партнерства відповідно до принципів відкритості, солідарності і взаємодопомоги, а також розвитку міждержавного співробітництва інклюзивного характеру.

Інклюзивне зростання - це зростання, яке дозволяє залучити більшу частину трудових ресурсів до ефективної економічної діяльності завдяки чому забезпечити більшій частині населення більш високий рівень життя. Значна увага приділяється розподільчим аспектам добробуту і доданню зростанню антидискримінаційної спрямованості. Люди можуть отримувати вигоди від економічного зростання як пасивні учасники, не приймаючи активної участі у збільшенні доходу або ВВП, а лише завдяки політиці перерозподілу. Це є досить поширеною практикою у більшості країн, і не тільки в бідних і тих, що розвиваються. Насправді, різниця між цими двома перспективами (люди, як активні або пасивні учасники, як виробники і споживачі, як актори або як клієнти) не так очевидна, як може здатися, адже інклюзивний розвиток вимагає, щоб люди були активно включені в процеси політичних, соціальних і економічних змін. Однак більша «справедливість» $\mathrm{i}$ «рівність» у розподілі доходів може одночасно сприяти виключенню більш вмотивованих і здатних груп населення від активної участі в цих процесах. До того, це виключає із бюджету країни величезні кошти, які доцільніше спрямувати на розвиток інфраструктури, найважливішого фактору інклюзивного зростання. Найгострішою є проблема нерівності, тобто низького ступеня інклюзивності економічного зростання, яка має місце в країнах із слаборозвинутими інфраструктурними мережами [2].

В Україні стратегія інклюзивного зростання починає набувати тільки обертів. Ще у 1992 р. приєдналася до стратегічного документу ООН «Порядок денний на XXI століття», підписала ряд міжнародних угод і договорів, які зобов'язують управлінські структури держави здійснювати розвиток на принципах збалансованості, а в 2015 р. було затверджено стратегію «Україна - 2020» року [3]. 
При розгляді проекту стратегії «Україна - 2030» звертає на себе увагу той факт, що поняттю «інклюзія» фактично не приділено уваги, хоч у вступній частині $€$ визначення понять «інклюзивність», «інклюзивне зростання», «інклюзивне суспільство» та «інклюзивні інституції». У самому ж тексті сутність цих понять ніяк не розкривається. Є враження, що ці поняття використовуються в тексті проекту Стратегії як свого роду декор, і майже завжди разом із поняттям «збалансований», яке в цьому контексті сприймається як синонім поняттю «інклюзивний». Однак у самому тексті проекту стратегії міститься чимало інструментів і механізмів щодо створення відповідного правового поля для інклюзивного зростання [2].

Для оцінки ефективності державної політики в цьому напрямі необхідно вимірювати ступінь інклюзивності зростання. Низка міжнародних організацій вже приступили до розроблення методичних рекомендацій щодо розрахунку індексу інклюзивного розвитку.

Так, на основі рейтингу Індексу інклюзивного розвитку (Inclusive Development Index, IDI) Україна зайняла 49 місце з 74-х серед країн, що розвиваються. У першу п'ятірку потрапили Литва, Угорщина, Азербайджан, Латвія і Польща. Сусідами України по рейтингу виявилися Танзанія і Йорданія. Натомість у 2017 році Україна була на 47 місці [4].

Індекс інклюзивного розвитку розраховується на основі 12 показників, об'єднаних в три групи, які оцінюють рівень економічного розвитку. У них входить зростання і розвиток (включаючи зростання ВВП, зайнятості, продуктивності праці, очікуваної тривалості життя), інклюзивність (медіанний дохід домогосподарств, рівень бідності та розшарування суспільства), наступність поколінь і стійкість (рівень заощаджень, демографічного навантаження, державного боргу і забруднення навколишнього середовища).

У доповіді ВЕФ підкреслюється, що ці індикатори оцінюють рівень економічного розвитку краще, ніж індикатор зростання ВВП. Подібний індекс найбільш вірно відображає економічний розвиток як країни загалом, так і її регіони, якщо метою є підвищення рівня життя населення.

Якщо розглядати регіональний розріз, то варто зазначити, що різних верствах населення вплив зростання відчувається неоднаково, настільки ж нерівномірно його вплив і в різних регіонах. Деякі регіони можуть швидко адаптуватися до соціально-економічного становища в країні, інші можуть відставати. У моделі інклюзивного розвитку перевагу у розвитку регіону відіграють різні економічні, соціальні чи політичні елементи. Наприклад, географічне розташування регіону, наявність в регіоні гірської місцевості, озер чи прилеглість їх до моря, наявність природних ресурсів чи будь які інші переваги.

Якщо розглядати приклад європейського то розвиток інклюзивності там пов'язується навіть з появою агломерацій, тобто коли фірми переїжджають міста, які розвиваються, тому, що туди вже перемістилися інші фрірми. Уряду здатні впливати на ці фактори, приймаючи рішення про те, куди вкладати кошти і де створювати інфраструктуру, роблячи, таким чином, рівномірніший розподіл повноважень на цій території. Однак вони не мають піддаватися спокусі протидіяти цим факторам, як би бажано це іноді не було з політичної точки зору. Регіональна політика не має намагатися створити просторове однаковість в моделях зростання і розвитку. Тобто має формуватися єдність, але не однаковість, відповідно до основного принципу регіональних програм розвитку Європейського Союзу.
Варто зазначити, що для розвитку інклюзивної економіки в регіонах України потрібно з часом зменшити розрив у доходах і багатстві між регіонами. Адже в нашому випадку в нас $€$ регіони, які в декілька разів $є$ багатшими, ніж інші регіони. Потрібно формувати таку регіональну політику, яка сприятиме згуртованості регіонів. Розумна регіональна політика в умовах інклюзивного розвитку має бути спрямована на інвестування в менш розвинені регіони, щоб зробити їх конкурентоспроможнішими і, відповідно, привабливішими для приватних інвесторів.

Ще одним чинником інклюзивного розвитку регіону може бути мобільність населення. Адже надлишок робочої сили в одних регіонах призводить до формування пропозиції робочої сили. У такому випадку ті регіони, які мають потребу в трудових ресурсах можуть і мають використовувати мобільне населення для розвитку своєї економіки. Тому мобільність трудових ресурсів формує новий етап розвитку регіону. Повною заміною вона не є, тому що деякі люди, особливо літні, ніколи не будуть відрізнятися мобільністю. А якщо взяти для прикладу ЄС як сукупність регіонів (країн) то, у багатьох країнах мобільності перешкоджають мовні відмінності.

В Україні таких проблем не має, тому цим чинником інклюзивності варто користуватися усім регіонам за потреби. Проте пріоритетність, що надається регіональними інвестиціями, має ґрунтуватися на мобільності тих людей, яким вони покликані допомогти. Тобто, коли стратегії спрямовані на підвищення мобільності робочої сили, їх вплив теж буде зростати. Для прикладу в $€ С$ мобільність $€$ довготривалою метою. Деякі бар'єри - на кшталт мовних - усунути важче, ніж інші. Також ЄС прагне, щоб сертифікати і ліцензії, отримані в одній країні, визнавалися і в інших країнах [5].

Політика інклюзивного розвитку в регіонах України має бути спрямована на те, щоб населення переміщалося 3 регіону в регіон по правильних причинах, в пошуках кращої роботи, а не через те, що там війна, а тут ні, чи там погане медичне забезпечення, а тут краще. Тому потрібно спрямовувати інвестиції в розвиток інфраструктури, адже є регіони, які не здатні ні через податки, ні через позики залучити достатньо грошей, щоб виконати ці завдання. Інвестиції в автоі залізні дороги і телекомунікації полегшують пересування робочої сили, хоча для певних видів економічної діяльності вони не настільки необхідні. Адже завдяки розвитку технологій зв'язку деякі послуги сьогодні можна надавати на відстані.

Також важливим елементом інклюзивного розвитку $є$ фіскальний аспект. Адже велика частина податків стягується на національному рівні і таким чином регіони отримують меншу фінансову можливість для свого розвитку. Та оскільки в Україні відбувається адміністративно-територіальна рефрорма та реформа децентралізації влади то сформовані об'єднані територіальні громади мають уже більші фінансові можливості на власний розвиток, тобто самостійно можуть розпоряджатися власними коштами.

Варто також зазначити, що регіональне розмаїття території України має свої переваги, адже це дозволяє формувати різні підходи інклюзивного розвитку кожного регіону відповідно до його специфіки та особливостей, а в підсумку отримати сумарний ефект на рівні держави, з виділеними сильними і слабкими сторонами кожного регіону. Це допоможе вчасно реагувати на ті виклики з якими регіон не зміг справитися самостійно і таким чином надавати йому поштовх для розвитку.

Вісник Сумського національного аграрного університету Серія «Економіка і менеджмент», випуск 2 (80), 2019 
Висновки. Як доведено, сьогодні щоб бути конкурентоспроможним і мати стале економічне зростання потрібно формувати інклюзивний розвиток економіки. Тому як на регіональному рівні, так і місцевому чи національному, розуміючи виклики майбутнього і глобальні проблеми, які постають перед людством щоденно, потрібно взяти курс на внутрішній розвиток в поєднанні з відкритістю та інноваційністю економіки регіонів. Це забезпечить в довгостроковій перспективі соціально-економічний ефект, стале економічне зростання, та покращення добробуту населення.

\section{Список літератури:}

1.Пэн Минкуан. Глобальный приоритет // ФОРУМ-2011: Проблемы модернизации в цивилизационном контексте. М., 2011. C. 213

2.Прогнімак О. Д. Інклюзивний розвиток України: перешкоди vs перспективи. Економічний вісник Донбасу, 2018. № 1(51). С. 187-197. $5 / 2015$

3.Про Стратегію сталого розвитку "Україна - 2020": Указ Президента України. URL: http://zakon3.rada.gov.ua/ laws/show/

4.Україна увійшла у ТОП-50 країн за інклюзивністю економічного розвитку. Бізнесінформ. URL: https://biz.nv.ua/ukr/markets/ukrajina-uvijshla-v-top-50-krajin-shcho-rozvivajutsja-po-inkljuzivnosti-ekonomichnoho-rozvitku2446681.html

5.Te Growth Report Strategies for Sustained Growth and Inclusive Development. Commission on growth and development. URL: $\quad$ https://openknowledge.worldbank.org/bitstream/handle/10986/6507/449860PUB0Box3101OFFICIALOUSE0ONLY1.pdf?sequence=1\&isAllowed=y

Popadynets N. M., PhD, Institute of Regional Research named after M.I. Dolishniy of the NAS of Ukraine (Lviv, Ukraine)

Priorities of inclusive development of Ukrainian regions.

Inclusive growth is the growth that allows attracting most of labour resources to efficient economic activity and thus securing higher level of life for larger share of population. Special attention is paid to distribution aspects of wellbeing and growing anti-discrimination. People can benefit from economic growth as passive actors, not participating actively in the increase of income or GDP but only due to distribution policy. It is a common practice in most countries, not only poor and developing ones. In this case, to successfully implement the plan the economy should be not only sustainable, but also more inclusive and impartial, because availability of all types of resources is of the major importance in maintaining inclusive economic growth directed at improvement of human wellbeing. Like in the world, in Ukraine inclusive development can play an essential role in the realities of administrative-territorial reform and become the basis for improvement of residents' wellbeing.

The paper aims to define major problems of inclusive development of Ukrainian regions.

The paper examines relevant issues of inclusive development. The importance of inclusive development of Ukrainian regions is substantiated and main preconditions of transition to inclusive development are outlined. Foreign experience of regions' inclusive development is examined. Main factors of inclusiveness and ways of their application are outlined. The paper proves that currently to be competitive and have sustainable economic growth it is necessary to form the inclusive economy development. Therefore, understanding the challenges and global problems emerging daily before humanity, it is necessary to address inclusive development at local or national levels combined with openness and innovative nature of regions' economy. It will secure the socio-economic effect, sustainable economic growth and improvement of human wellbeing in the long-term perspective.

Keywords: inclusive development, investment, innovations, competition, mobility of population, Ukrainian regions.

Дата надходження до редакції: 07.02.2019 р. 